\title{
保育施設における屋外環境と園外活動の実態からみた 地域資源のあり方に関する研究 \\ 一横浜市を対象としたアンケート調査よりー \\ A STUDY ON REGIONAL RESOURCES UTILIZED BY DAY NURSERIES FROM THE VIEW POINT OF OUTDOOR ACTIVITY SPACE AND ACTIVITIES IN THE CHILD-CARE FACILITIES \\ - Questionnaire survey on outdoor activities for day nurseries in Yokohama -
}

$$
\begin{aligned}
& \text { 松橋圭子*1, 三輪律 } \text { 江 }^{* 2} \text {, 田中稲子*3 }{ }^{*} \text {, 谷口 新*4 } \\
& \text { 大原一興*5, 藤岡泰寛 }{ }^{* 6}
\end{aligned}
$$

\begin{abstract}
In this study, the author attempts to elucidate the regional resources of day nurseries from the view point of the outdoor activities. The authors conducted the questionnaire survey to day nurseries in Yokohama City. The results showed that $70 \%$ of the authorized day nurseries had the outdoor activities more than once a week, and $84 \%$ of the Yokohama day nurseries had them almost every day. To compare with the authorized day nurseries, the Yokohama day nurseries had smaller play ground, and they always use regional resources. Moreover, most of the day nurseries use not only the parks but also the roads to childcare and education place corresponding to the childcare aim.
\end{abstract}

Keywords : daynursery, outdoor activity space, outdoor activity for day nursery, regional resource, route, park 保育施設，屋外活動スペース，園外活動，地域資源，道，公園

\section{1. 研究の背景と目的}

近年、少子化の進展に伴い児童数が減少する一方で共働きの増加や ライフスタイルの変化から保育所の需要は増加している注1)。特に都 市部においては保育所に入所したくても施設不足により入所できな い待機児童問題が依然として深刻な課題となっており、認可保育所で は増設のほか定員枠を広げて入所を受け入れるケースも多くみられ る。また認可保育所に比べて設置しや寸い自治体独自の認可基準に基 づく自治体認定型保育施設注 2) の拡大もみられ、こうした施設は近年 待機児童の重要な受け典となっている。

保育施設の設置基準については、児童福祉法に基づく『児童福祉施 設設置最低基準(S23.12 省令、H17.4.1 改正)』において「満 2 歳以上 の幼览を入所させる保育所には、園庭等の屋外遊觑場 (基準 $3.3 \mathrm{~m}^{2} /$ 幼児 1 人当り)の設置が必要」とされており、これまで室内だけでは なく屋外環境についても重視されてきた。幼児期に多くの時間を過ご 寸保育施設においては、充分な外遊びが行える環境の整備と確保が 必要とされ、社会的な背景からもその傾向は近年更に高まりつつある 注 3) と考えられるが、ここ数年、定員を超えて入所を受け入れている 認可保育所や新設される施設では子どもの人数に応じた屋外遊び場 所の確保が困難となっている。このことから 2001 年 3 月以降、『待機
児童解消に向けた児童福祉施設最低基準に係る留意事項等について』 により屋外遊戯場 (園庭) を所有できない施設に対してはその代替場 所として施設周辺にある公園・広場・神社等を認めるといった施設設 置基準の緩和注 4) が講じられてきた。もはや認可・認可外に関わらず 施設内だけでは子どもの体力・様々な体験等を目的とした屋外保育活 動が行いづらい環境にあることが予想され 1)，2)、保育施設にとって 日常的に施設周辺地域に出かけ活動を行う園外活動注5) がより重要な ものとなっていることが推測される。

これまで保育施設に関する研究報告は保育学をはじめ多くの分野 でみられ、建築計画学においても保育環境としての遊び空間のあり方 や、生活寸る場としての施設空間構成に求められる条件等追究されて きた。最近では幼保一体型施設の現況報告のほか子どもの行動場面や 社会性の獲得に着目し空間との相互関係についての考察も行われて いるが ${ }^{3 \sim 5}$ ，既往研究の多くが施設内環境（平面計画・物的環境）に 視点が置かれている。屋外の保育活動に目を向けると、都市部の事例 として東京都の団地敷地内の保育施設を対象として、同敷地内の公園 における外遊びの質を論じたものがあげられる ${ }^{2)}$ 。また、筆者らは都 市部でも施設設置基準の緩和など待機児童数の解消策を急激に図っ た横浜市を対象として保育施設の園外活動の実態調查を行い、保育施
*1 鎌倉女子大学 非常勤講師 ·博士 (工学) 横浜国立大学地域実践教育研究センター 准教授 ·博士 (工学)

*3 横浜国立大学学際プロジェクト研究センター 助教・博士 (工学)

*4 大妻女子大学社会情報学部 専任講師 · 博士 (工学)

*5 横浜国立大学大学院工学研究院 教授. 工博

*6 横浜国立大学大学院工学研究院 講師 · 博士 (工学)
Part-time Lecturer, Kamakura Women's Univ., Dr. Eng.

Assoc. Prof., Global-Local Education and Research Center, Yokohama National Univ., Dr. Eng.

Assistant Prof., IRC, Yokohama National Univ., Dr. Eng.

Lecturer, School of Social Information Studies, Otsuma Women's Univ., Dr. Eng.

Prof., Faculty of Engineering, Yokohama National Univ., Dr. Eng.

Lecturer, Faculty of Engineering, Yokohama National Univ., Dr. Eng. 


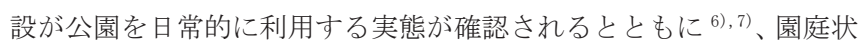
況と公園利用実態の関係から、施設敷地内の屋外活動場所が限られた 環境にあり近隣の公園でそれを補完する様子が明らかにされつつあ る ${ }^{8)}$ 。しかしながら、これらは施設周辺地域の広範な視点から公園以 外の空間も含めた地域資源注 6) の利用実態を捉えたものではなく、今 後更に屋外保育環境の悪化が懸念される中、これらを解決するような 方策を示すことは喫緊の課題と考える。

そこで本研究では、横浜市を対象として認可保育所をはじめ今後更 に拡大が予想される自治体認定型保育施設を取り上げ、これまでの結 果を踏まえた上で、保育施設の敷地内の屋外環境の実態 (第 3 章) とあ わせて園外活動からみた地域資源の利用状況 (第 4 章) とニーズ (第 5 章)を把握し、日常的な保育環境としての地域資源のあり方について 地域施設計画の視点から考察を行い、屋外の保育環境を考慮した施設 整備拡充に向けた基礎的資料を得ることを目的とする。

\section{2. 研究の方法と概要}

本研究で対象と寸る横浜市は 3 歳未満児の待機児童の顕在化に対 応寸る為、認可保育所の新設や受け入れ人数の増加を図るほか、自治 体認定型保育施設として「横浜保育室注 7)」の設置を進めることでこ こ数年待機児童削減を目指した取り組みがみられる地域である（図 1)。横浜市にある全保育施設のうち、「認可保育所」と横浜市の設置 基準に基づく「横浜保育室 (認可外保育施設)」の全施設 (2007 年 6 月 現在) 対象に施設の敷地内屋外活動環境(施設概要·施設内屋外活動 環境の実態と評価) 及び園外活動の状況 (頻度・移動形態・活動場所 選択基準・地域交流)についてアンケート調査注 8) を実施したが (平均 回収率 $34.6 \%$ )、表 1 に示したアンケートの質問項目については、既 往研究 ${ }^{9 \sim 10)}$ に基づいて設定した。更にその中から 12 施設に対してヒ アリング及び現地調查 (2007 年 11 月〜2008 年 1 月) 注9) を行ったが、本 稿ではそれらをアンケート調查の結果を補完するものとして捉え併 せた報告を行う。尚、回答者の属性は認可保育所の $85 \%$ 主任保育士 または施設長、横浜保育室の $86 \%$ が主任保育士であることから施設の 状況を充分に把握している者と思われる。

\section{3. 保育施設の立地特性と敷地内屋外活動環境の実態 \\ 3-1. 施設形態別にみた立地特性}

今回、回答のあった認可保育所 138 施設のうち屋外遊戯場 (園庭) が敷地外にある 3 施設 (私立)を除いて他はすべて敷地内に設置され ていた。それに対して、図 2 より横浜保育室の園庭「あり」は 3 割弱 に留まっていたが、園庭を保有しない施設のうち $55 \%$ が『子どもの人 数が 10 人未満』、 $77.8 \%$ 『 『2001 年施設設置基準改正後以降に設置さ れた施設』であった。施設の建物形態は、認可保育所・公立の 9 割以 上、私立の約 8 割が独立した建物であるのに対して、図 3 で示すよう に横浜保育室の約 7 割は併設であることが既往研究で報告されてい るが、横浜保育室では「住居とオフィス・店舗との併設 (44.8\%)」が 最も多く、「住居のみ」との併設は $24.1 \%$ あった(図 4)。認可保育所・

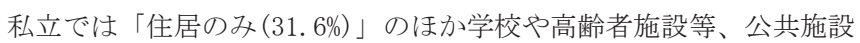
との併設 $(21.1 \%)$ が比較的多くみられ、施設形態により特徵がみられ た。更に横浜保育室の場合、 $72 \%$ が 3 階建て以上の建物に設置されて いる状況であることからオフィスや商業ビルの一角に併設されるケ ースの多さが示され、こうした立地面からも屋外活動スペース確保の

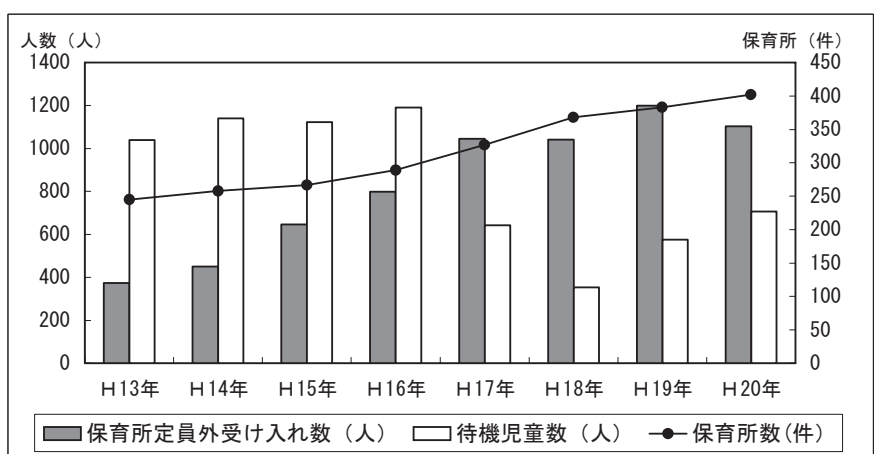

図 1 横浜市における保育所数と待機児童数等の推移

表 1 アンケート調査概要

\begin{tabular}{|c|c|c|c|c|c|c|}
\hline \multicolumn{7}{|c|}{ 調査期間と方法 } \\
\hline \multicolumn{7}{|c|}{ 2007年7月～8月／郵送による配布·回収 } \\
\hline \multicolumn{7}{|c|}{ 調査対象 } \\
\hline \multicolumn{7}{|c|}{ 横浜市の全認可保育所·全横浜保育室(2007年6月現在) } \\
\hline \multirow{2}{*}{\multicolumn{2}{|c|}{ 種別 }} & \multirow{2}{*}{ 施設数 } & \multirow{2}{*}{ 定員 } & \multicolumn{3}{|c|}{ アンケート回答率 } \\
\hline & & & & 配布数 & 回収数 & 回収率 \\
\hline \multirow{3}{*}{ 認可保育所 } & 全体 & 390 & 33944 & 390 & 138 & $35.4 \%$ \\
\hline & 公立(含·公営民設2箇所) & 110 & 9277 & 110 & 48 & $43.6 \%$ \\
\hline & 私立 & 280 & 24667 & 280 & 90 & $32.1 \%$ \\
\hline 認可外保育施設 & 横浜保育室 & 133 & 4132 & 133 & 43 & $32.3 \%$ \\
\hline \multicolumn{4}{|r|}{ 計 } & 523 & 181 & $34.6 \%$ \\
\hline \multicolumn{7}{|c|}{ 調査内容 } \\
\hline \multicolumn{7}{|c|}{ 1）基本属性：回答者·施設·屋外遊戯場について 10項目 } \\
\hline \multicolumn{7}{|c|}{$\begin{array}{l}\text { 2）施設敷地内の屋外活動環境の実態と評価: 園庭の有無と面積·屋外遊具·設備·自然環境· } \\
\text { 性等 } 10 \text { 項目 }\end{array}$} \\
\hline \multicolumn{7}{|c|}{$\begin{array}{l}\text { 屋外における園外活動の実態:年齢別活動頻度·時間·移動経路と形態·保育のねらいに対 } \\
\text { 応する活動場所(公園、寺社、商店街、道、その他) } 10 \text { 項目 }\end{array}$} \\
\hline \multicolumn{7}{|c|}{ 4）公園の利用状況と評価 :公園名·頻度·滞在時間·評価·重視点·要望等 6項目 } \\
\hline \multicolumn{7}{|c|}{ 5）地域交流の実態:公園での交流頻度·交流内容·管理団体等 10 項目 } \\
\hline \multicolumn{7}{|c|}{$\begin{array}{l}\text { 【自由記述項目(非定型)】園庭代わりに利用する場所/敷地内屋外スペースを活用する際にエ } \\
\text { 夫している点/移動の形態/子ども達が好む園外活動場所について/公園に対する要望 }\end{array}$} \\
\hline
\end{tabular}

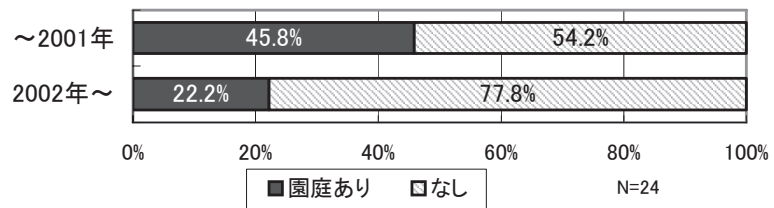

図 2 設立年度と園庭の有無(横浜保育室)

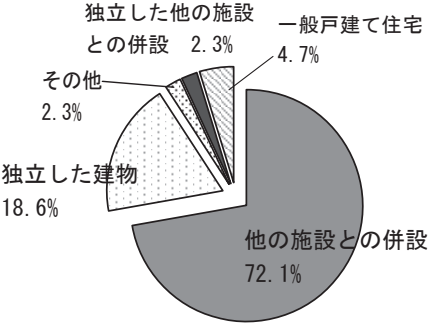

図 3 建物の形態(横浜保育室)

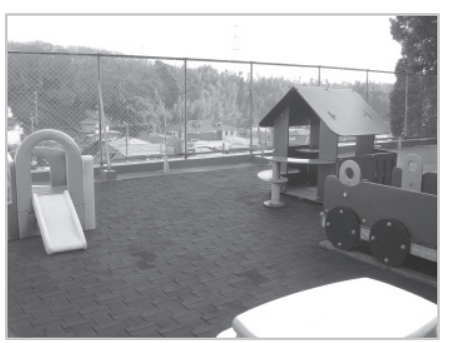

写真 1 遊具が設置された屋上の事例 (認可保育所)

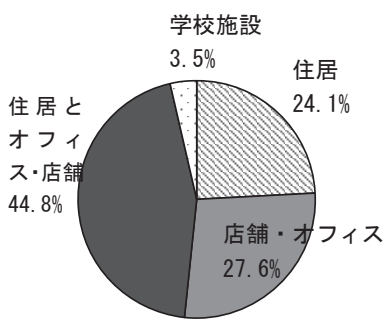

図 4 建物の併設状況(横浜保育室)

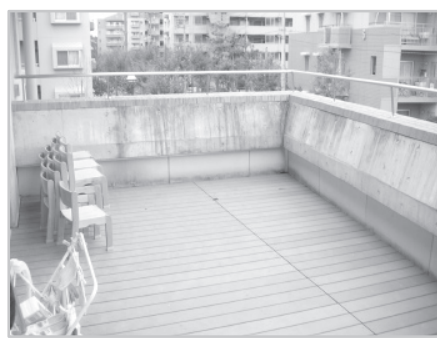

写真 2 仮設プールの設置も可能な ベランダの事例(認可保育所) 
難しさが窥える。

更に各施設から最寄り駅までの直線距離と敷地内屋外空地面積 注 10) を実測し、その関倸性を概観してみてみると、横浜保育室の駅か らの平均距離は $506.8 \mathrm{~m}$ で、認可保育所 $(791.9 \mathrm{~m})$ に比べて駅近く に設置されるケースの多さが確認された。また览童一人あたりの屋外 空地面積の平均は認可保育では $9.9 \mathrm{~m}^{2}$ であったのに対して横浜保育 室では $2.7 \mathrm{~m}^{2}$ と開きがみられ、全体に駅近くになるほど施設の屋外空 地面積は狭くなる傾向が窥える。

\section{3-2. 敷地内屋外活動環境の現況}

次に各施設の敷地内における屋外活動環境についてみてみる。園庭 を除く屋上・ベランダ等(前頁写真 1·2) の屋外活動スペース注11) の利 用状況について図 5 をみてみると、デッキ(認可保育所 $38.4 \%$ ・横浜 保育室 $18.6 \%$ ) 2 階以上のベランダ (認可保育所 $39.9 \%$ ・横浜保育室 $20.9 \%$ ) の利用率は全体の 3 割強、屋上(認可保育所 $21.7 \%$ ・横浜保育 室 $11.6 \%$ )については全体の約 2 割が利用していた。認可保育所全体 では砂場や固定遊具、水飲み場のほか花壇の設置率が高く、広場 (地 面) は土などの自然素材 (認可公立 $68.1 \%$ 、私立 $56.1 \%$ ) が比較的多くみ られた。また屋外活動スペースを利用寸る上で行っている工夫として は、「庭の一部を畑にして野菜を育てる」「直射日光を防ぐ為に日よけ ネットやテントを設置」「異年齢交流を大切にしたいが園庭が狭い為 年齢別に活動時間を分けて利用する」等の回答が自由記述の中で多く みられた。

横浜保育室では園庭がない場合でも、デッキやベランダの利用が若 干みられ(デッキ $15.0 \%$ ・ベランダ 15.0\%) 園庭の代替として使われて いる様子が窥えたほか、全体では砂場 (43.5\%) や仮設プール (47.8\%) の利用が比較的多く、屋上やベランダの床にはゴムチップや人工芝、 マット類を敷いて僅かなスペースでも低年齢児が使いやすいように 工夫しながら利用している様子が自由記述からも捉えられた。しかし 図 6 に示寸ように、園庭や園庭以外の屋外活動スペースも「利用しな い」もしくは「ない」施設が 5 割近く存在することも確認された。

\section{3-3. 敷地内屋外活動環境に対する評価}

施設が保有する屋外活動スペースの環境に対する施設側からみた 評価(広さ・遊具、設備等・自然環境・安全性)では、『広さ』や『遊 具・設備』、『自然環境』については認可保育所・私立や横浜保育室に 比べて認可保育所・公立では比較的充分であると捉えている割合が高 かった。特に横浜保育室では『広さ』について充分ではないと評価し ている割合が多く、「どちらかというと充分ではない」まで含めると 全体の 6 割以上を占め、園庭を保有している場合でも約 6 割が充分で はないと捉えていることがわかった。更に『遊具・設備』面でも、認 可保育所と比較した場合評価の低さが目立っていたが、『安全性』に ついては「充分である (33.3\%)」と感じている割合が比較的高く、認 可保育所を上回っていたのが特徴といえる。

しかし、今回の調查では横浜保育室に限らず、保有する屋外活動ス ペースの環境に対して認可保育所の公立・私立ともに充分ではないと 感じている施設が多いという実態が図 7 からも捉えられ、特に私立で はその『広さ』について「どちらかというと充分ではない(27.6\%)」

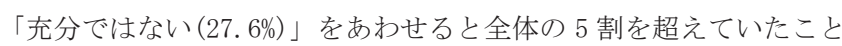
から、多くの保育施設が敷地内だけでは充分な屋外保育活動を行うこ とが難しい状況にあることが推測される。

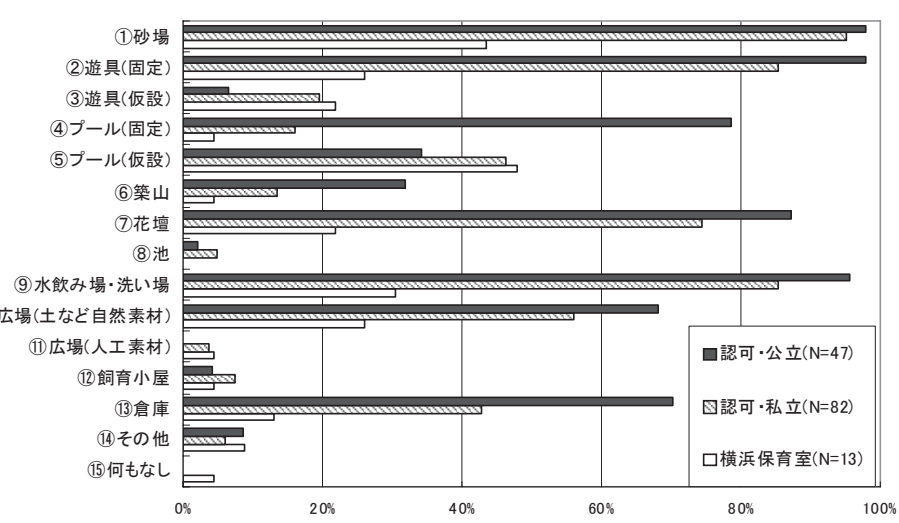

図 5 屋外活動スペース(園庭)にあるもの

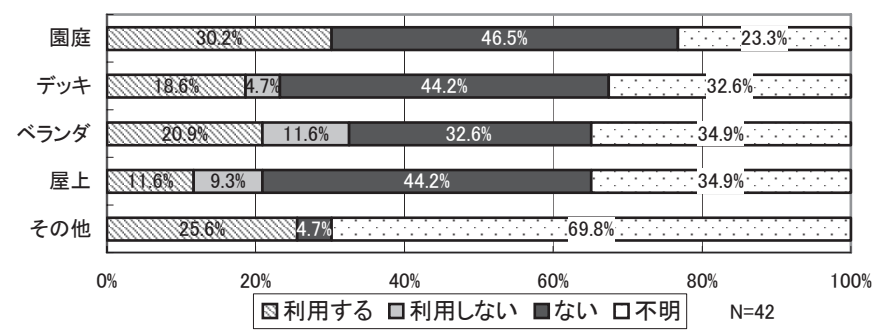

図 6 屋外活動スペースの利用実態(横浜保育室)

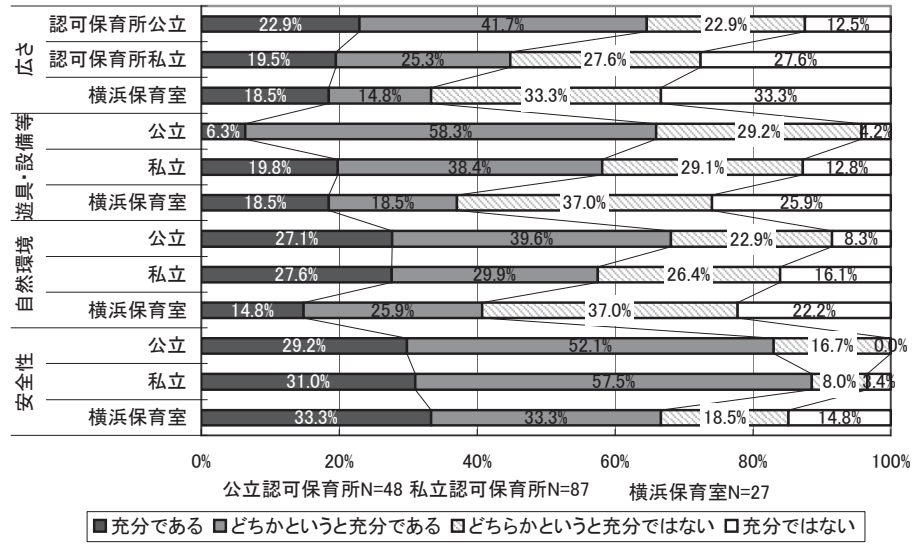

図 7 屋外活動スペースに対する評価

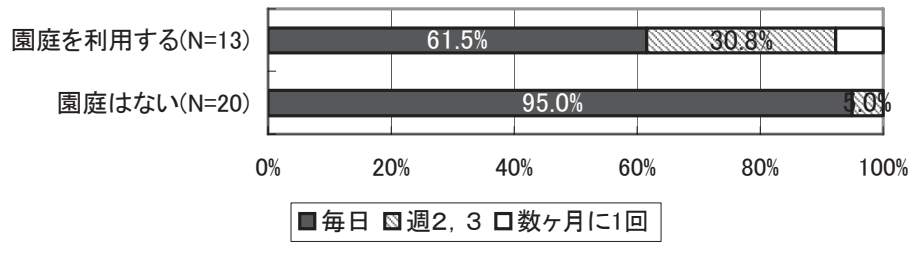

図 8 園庭の有無と園外活動頻度(横浜保育室)

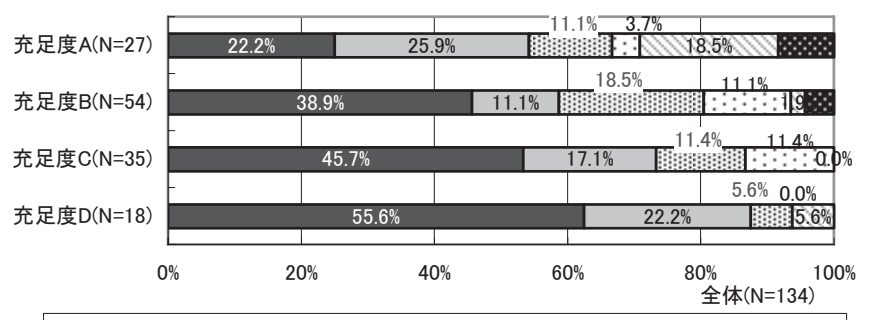

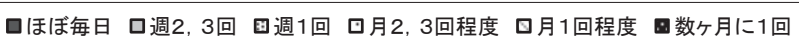

図 9 屋外活動スペースに対する充足度と園外活動頻度(認可保育所) 


\section{4. 保育施設における園外活動の状況}

\section{4-1. 敷地内屋外活動環境亡園外活動の頻度}

前頁図 8 より、施設形態による立地的な特徵と敷地内屋外活動環 境の現況を踏まえた上で保育施設が行っている園外活動についてみ てみると、横浜保育室全体では 83.7\%が「ほぼ毎日」園外に出かけ、 園庭がない場合では実に $95.0 \%$ 施設で「ほぼ毎日」実施されていた。 また認可保育所全体でも 7 割が「週 1 回以上」、約 6 割が「週 2 3 回以上」と非常に高い頻度で園外に出かけている実態が既往研究 ${ }^{6)}$ から明らかになっているが、具体的な活動時間は、多くの施設が午前 中を中心に『60 分以上 (57.6\%)』敷地外で活動していた。更に認可保 育所では、保有する敷地内屋外活動環境に対する総合的な評価 (充足 度）注 12) が低い傾向にある施設ほど頻繁に園外活動を行っている様 子も捉えられた(前頁図 9)。

また図 10 では、全体に児童一人当たりの屋外空地面積が狭くなる ほど園外活動頻度は高くなる傾向が示され、園外に出ることで屋外活 動を補填している様子が窺えた。しかし今回の調査ではとれと同時に ある程度の広さの園庭を保有しながらも園外活動は非常に高い頻度 で行われていることも確認され(表 2)、ヒアリング調査からは施設側 の子どもの屋外活動に対する関心と意識の高さが捉えられた。こうし たことからも園外活動が保育施設全般にとって日常的且つ積極的な 保育プログラムに位置づけられていることが裏づけられた。

\section{4-2. 保育のねらいと園外活動場所}

普段園外活動を行なう際に利用寸る場所について図 11 に示した保 育の衫らい注 13) に対応させながら選択 (複数回答) してもらった結果、 園外活動場所の指摘数は全体に 1 施設で $3 \sim 4$ 箇所が多く(約 6 割)、 認可保育所の 1 割強では $5 \sim 7$ 箇所と数多く挙げられていた。また園 外に出る頻度が高い施設ほど利用箇所数も多く、地域の中にあるいく つかの活動場所の中から保育のねらいに対応させながら出かける場 所を選択している様子が窥えた。利用する場所としては全体に『公園』 と『道』の指摘が目立ち、『公園』については、「体力増進や運動能力 の向上」「自然や生き物との触れ合い」を目的として認可保育所の約 8 割、横浜保育室では 9 割以上の施設が利用し、また多くの施設は地 域との交流を意識して公園に出かけている様子が捉えられたことか ら保育施設にとって公園が改めて重要な活動場所であることが確認 された。特に充分な屋外活動スペースの確保が難しい状況にある横浜

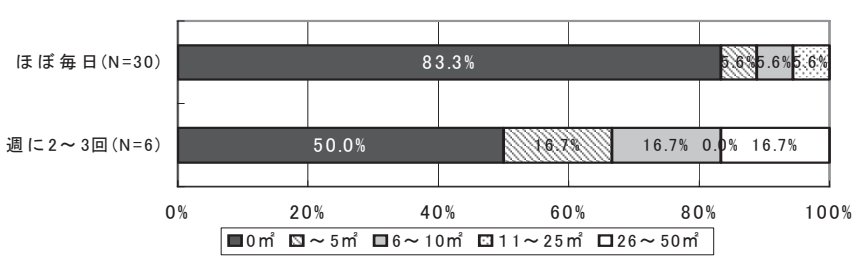

図 10 児童一人当たりの屋外空地面積と園外活動の頻度 (横浜保育室)

表 2 児童一人当たりの屋外空地面積と園外活動頻度 (施設形態別)

\begin{tabular}{|c|c|c|c|c|c|c|c|c|c|}
\hline & \multirow[b]{2}{*}{ 園外活動頻度 } & \multirow[b]{2}{*}{ 合計 } & \multirow[b]{2}{*}{$\%$} & \multicolumn{6}{|c|}{ 児童一人当たりの屋外空地面積 度数(件) } \\
\hline & & & & $0 \mathrm{~m}^{2}$ & $\sim 5 \mathrm{~m}^{2}$ 未満 & $\begin{array}{l}5 \sim 10 m^{2} \text { 未满 } \\
\end{array}$ & $\begin{array}{c}10 \sim 25 \mathrm{~m}^{2} \\
\text { 未満 }\end{array}$ & $\begin{array}{c}25 \sim 50 \mathrm{~m}^{2} \\
\text { 未満 }\end{array}$ & $\underset{\mid 50 \mathrm{~m}^{2} \text { 以上 }}{\sim}$ \\
\hline \multirow{6}{*}{ 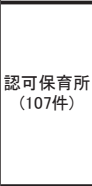 } & ほぼ毎日 & 50 & $46.7 \%$ & $\overline{6}$ & 15 & 15 & 11 & 2 & 1 \\
\hline & 週に $=2 \sim 3$ 回 & 21 & $19.6 \%$ & 4 & 3 & 7 & 5 & 2 & 0 \\
\hline & 週に1回 & 16 & $15.0 \%$ & 0 & 3 & 4 & 8 & 1 & 0 \\
\hline & 月に2〜3回 & 9 & $8.4 \%$ & 0 & 0 & 7 & 2 & 0 & 0 \\
\hline & 月に1回 & 7 & $6.5 \%$ & 0 & 0 & 5 & 2 & 0 & 0 \\
\hline & その他 & 4 & $3.7 \%$ & 1 & 0 & 2 & 1 & 0 & 0 \\
\hline \multirow{6}{*}{$\begin{array}{c}\text { 横浜保育室 } \\
\text { (433件) }\end{array}$} & ほぼ毎日 & 36 & $83.7 \%$ & 30 & 2 & 2 & 2 & 0 & 0 \\
\hline & 週に2 2 3回 & 6 & $14.0 \%$ & 3 & 1 & 0 & 1 & 1 & 0 \\
\hline & 週に1回 & 0 & $0.0 \%$ & 0 & 0 & 0 & 0 & 0 & 0 \\
\hline & 月に $2 \sim 3$ 回 & 0 & $0.0 \%$ & 0 & 0 & 0 & 0 & 0 & 0 \\
\hline & 月に 1 回 & 0 & $0.0 \%$ & 0 & 0 & 0 & 0 & 0 & 0 \\
\hline & その他 & 1 & $2.3 \%$ & 0 & 0 & 0 & 1 & 0 & 0 \\
\hline
\end{tabular}

$0 \% \quad \because \quad 0 \%$ 以上 10\%未満 $\square 10 \%$ 以上 30\%未満 $\square 30 \%$ 以上

保育室では、定期的に利用する敷地外・園庭代わりの場所として 83. 7\%が『公園』を挙げていた。また『道』については、「交通ルール の習得」だけではなく「体力増進や運動能力の向上 (認可・公立

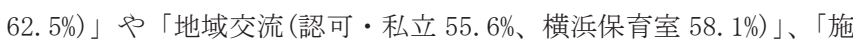
設・生活への関心(横浜保育室 58.1\%)」を礼らいとして利用する割合 が高く、公園と同様に多くのねらいを充足できる重要な活動場所であ ることがわかった。

その他「施設・生活への関心」を衫らいとして認可保育所・公立 (50.0\%) と横浜保育室 $(53.5 \%)$ では『商店街』の指摘が比較的多くみら れ、特に横浜保育室では「地域交流」を求めて『道』の利用とともに、 商店街に頻繁に立ち寄っている様子が窅えた。また園庭がある横浜保 育室に比べて「ない」施設の特徴としては『商店街』の指摘が目立ち、

「施設・生活への関心(園庭あり 30.8\%・なし 65.0\%)」や「地域交流 (園

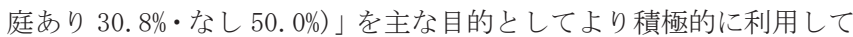
いた。

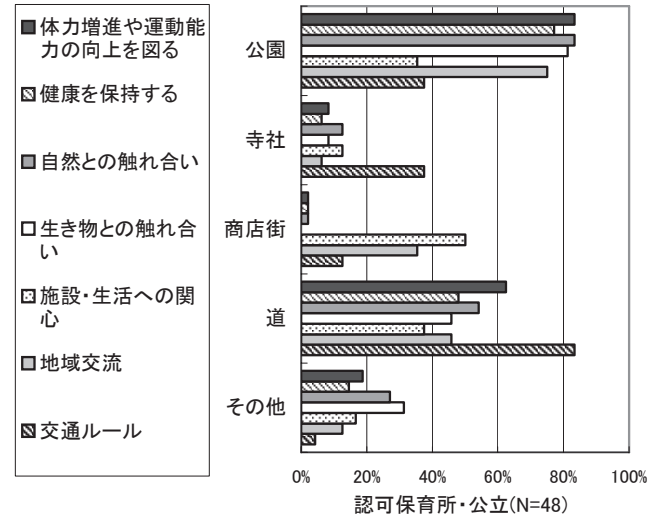

図 11 保育の衫らいと園外活動場所
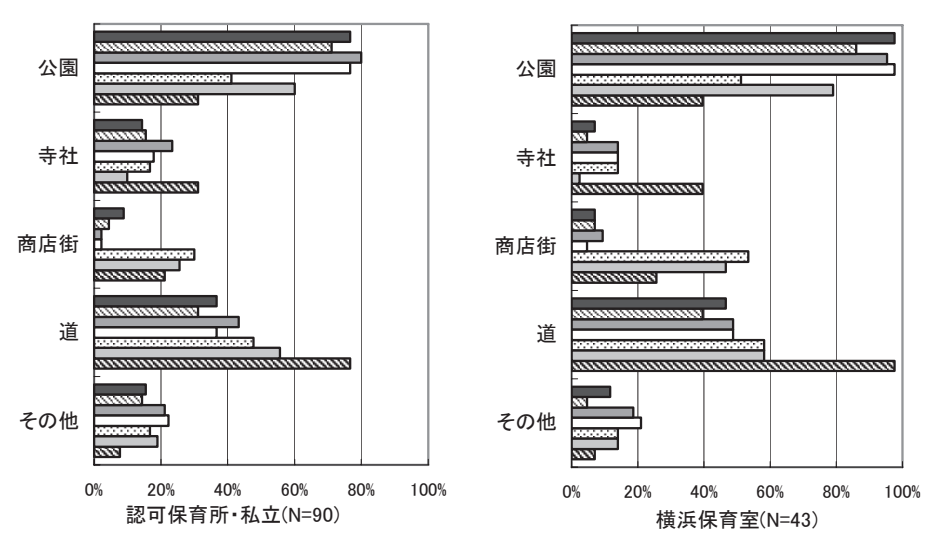


\section{4-3. 園外活動からみた地域住民との交流}

保育施設にとって『公園』や『道』が重要な活動拠点と位置付けら れている実態とともに地域交流を意識して出かけている様子が示唆 されたが、園外活動の広がりを支える為には地域住民の理解と見守り が欠かせない要件と考え、園外活動に伴い発生する地域の人たちとの 交流について着目してみる。

まず図 12 で示すように、園外活動を行う際には公園を利用する地 域の子育て家庭に対して全体の 7 割以上が『挨拶』を「必ずする」と 回答していた。『子どもを遊びに誘う』については「必ずする・よく する」をあわせた割合は全体の $34.8 \%$ 、「たまにする」まで含める と $77.5 \%$ (認可公立 $93.8 \%$ ・私立 $66.7 \%$ ・横浜保育室 $72.1 \%$ ) が行ってお り、挨拶はもとより地域の子ども達を遊びに誘い、子育て家庭の相談 に応じている様子が今回の調査から窥うことができた。その他、認可 保育所・公立では実施される行事の多さからか『園庭開放など園の行 事案内をする』割合が高く(必ずする $31.3 \%$ 、よくする $37.5 \%$ )、私立 (必 ずする $12.2 \%$ 、よくする $13.3 \%$ ) とは開きがみられた。また『園の子ど もが地域の人たちと交流する』では「必ずする・よくする」をあわせ た割合は全体に 4 割前後みられ「たまにする」まで含めると 8 割を越 えていたことから、公園において地域の人たちとの日常的な関わりが 実践されていることが明らかとなった。しかし、その一方で地域行事 への参加については「全くしない(認可公立 $68.8 \%$ 、私立 $51.1 \%$ 、横浜 保育室 $55.8 \%$ 」の割合が目立っていた。

また園庭がある横浜保育室とない施設を比較した場合、「たまにす る」まであわせた割合では、『挨拶をする（園庭あり $61.5 \%$ 、なし 95. 0\%))』や『子どもを遊びに誘う(園庭あり 46.2\%、なし $85.0 \%$ ) 』 『園の子どもが地域の人たちと交流寸る (園庭あり $69.3 \%$ 、なし 90. $0 \%)$ )』の項目で差がみられ、園庭がない施設では公園に滞在する 時間が長いことも(滞在時間 70 分以上: 園庭あり $0 \%$ 、なし $35 \%$ ) 地域の 人との関わりに影響を及ぼしていると考えられる。

また目的場所というよりも低年齢児にとっては僅かでも施設の外 に出ること (外出) 自体が心身の成長・発達を促す上で大きな意味を持 ち、更に『道』を「歩くこと」で多くの齐らいを習得できるというこ とがヒアリング調査からも裏づけされた。普段地域の中を散歩する中 で、子どもは商店街の人や近隣住民から声をかけてもらい、飼ってい る動物や庭の草花を見せてもらうなど自然な関わりがもたれていた (自由記述とヒアリングより)。『道』は地域住民との日常的な触れ合 いが期待できる貴重な交流空間であるという実態も今回の調查から みえてきた。

\section{5. 園外活動の場としての地域資源に対するニーズ 5-1. 経路の選択基準と利用する道の特徴}

保育施設と地域の中にある活動場所をつなぐ上で道は重要な存在 であることから移動経路について概観してみる。まず移動の手段につ いては記述式で回答を得たが、認可保育所では $9.4 \%$ 、横浜保育室で は27.9\%がバギーを使用することがあると回答した。このとき徒歩と バギーの併用が殆どで、2 歳児クラスにおいて月齢が低い子どもを対 象に年度始めのみ利用寸ると回答した施設が多く、バギーのみでの移 動は 1 施設であった。それ以外は子ども同士が手をつないで徒歩にて 移動しており、本研究の分析対象においては殆じが「徒歩」での移動 であったと推察される。移動時の子どもの人数は横浜保育室では 10

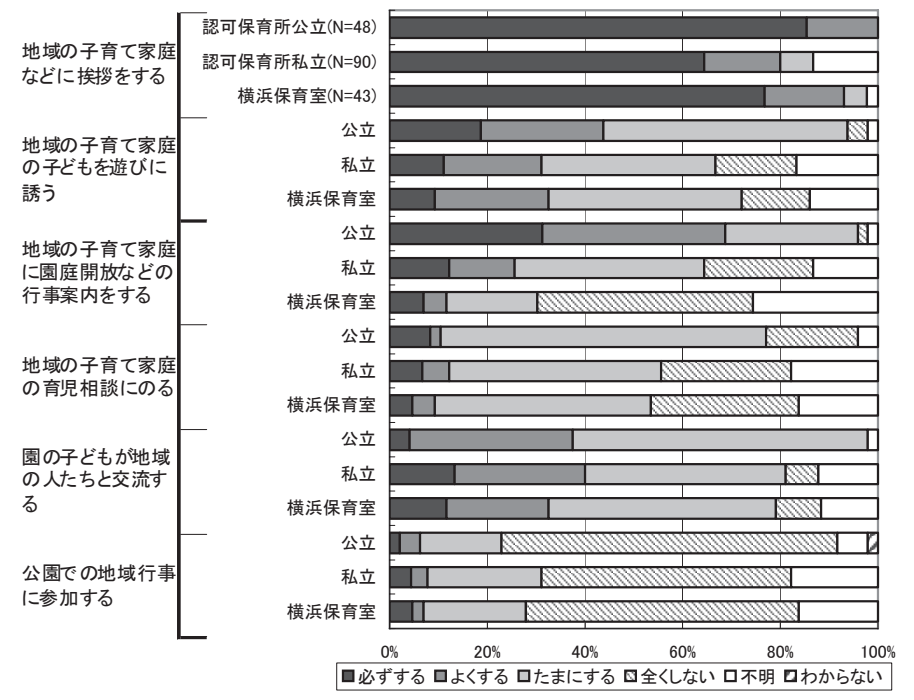

図 12 公園での地域交流の実態

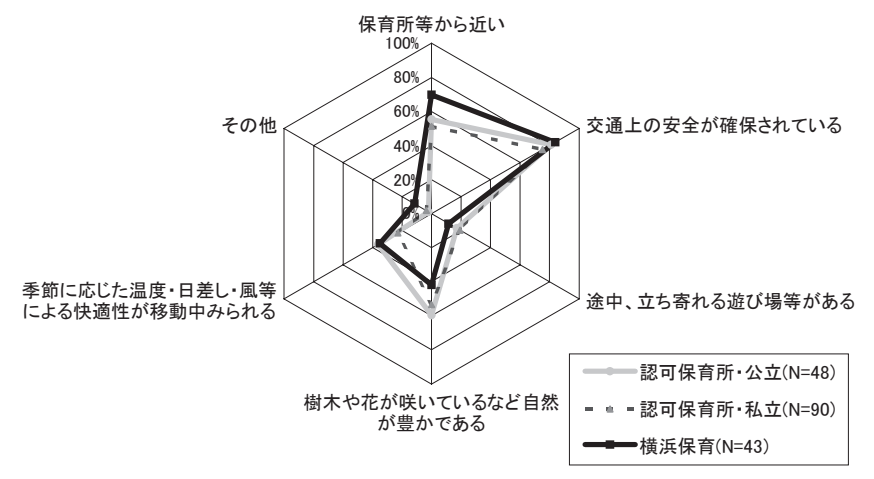

図 13 移動の際に重視する点

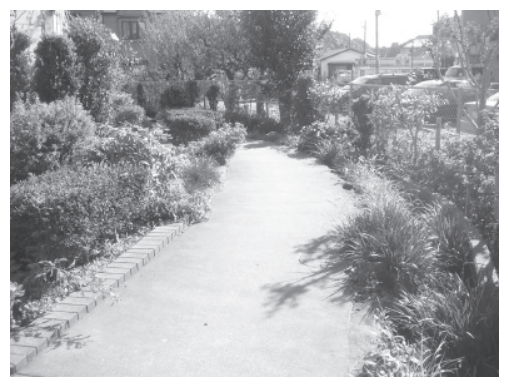

写真 4 自然豊かな遊歩道

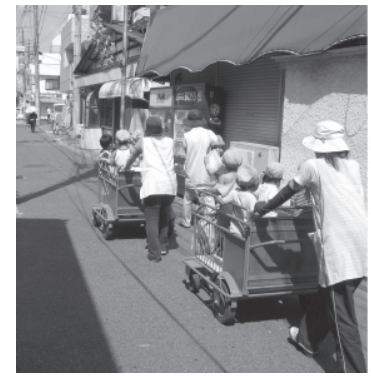

写真 5 商店街の中をバギーで 移動する様子(横浜保育室)

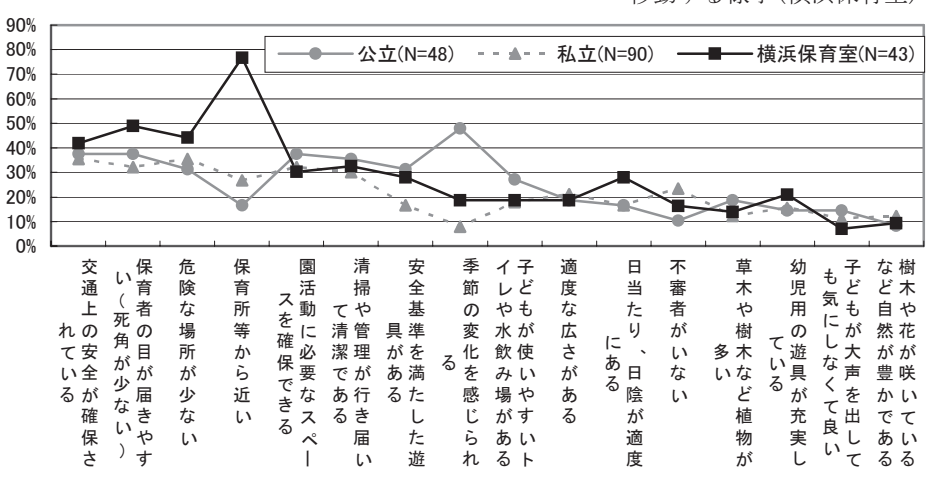

図 14 公園を選択する際に重視する点(複数回答)

人以下が 4 割、 20 人以下が 3 割強で、認可保育所(公立・私立ともに $10 \sim 20$ 人以下が 5 割強) と比べると少人数規模での移動といえる。移 動の際に重視する点を項目の中から複数回答 (3 項目まで) で求めた 
結果を図 13 に示したが、「交通上の安全が確保されている(全体 74. $4 \%$ )」点が最も重視され、特に駅前に設置されるケースが多い横浜 保育室 (83.7\%) ではその傾向が強かった。また認可保育所と比べて「保

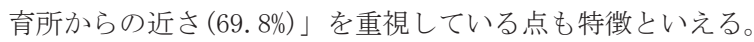

全体に安全面だけではなく自然環境も重視している傾向がヒアリ ング調査からも示されたが、特に認可保育所では樹木や花といった自 然と触れ合いができる道を求める傾向がみられ、季節の変化にあわせ てお散歩ルートを変える等工夫しながら施設周辺を幅広く動き回っ ている様子が窺えた(前頁写真 4 参照)。

更に普段地域の中を散歩する中で子どもたちが「お楽しみスポット 注 14)」として捉えている場所を自由記述により回答を求めたところ、 全体に「電車やバスが見える歩道橋(認可保育所 $23.4 \%$ ・横浜保育室 $52.6 \%) 」 か ゙$ 多く挙げられ、「線路沿いの道」や「駅前・バスが見える ロータリー」等乗り物を見ることができる安全な道を選んで移動して いると答えた施設が多かった。また犬や鳥、魚や虫といった生き物が 見られる場所(道)も多く挙げられていたが(認可保育所 $38.3 \%$ 、横浜 保育室 $52.6 \%$ )、特に『歩道橋』は安全で眺めがよいことから積極的 にお散歩ルートに取り入れられており、ヒアリング調査からも「歩道 橋の上り下りは子どもの体力向上を促進する上で有効である」という 回答が多く得られた。

\section{5-2. 公園に対する評価と選択基準}

屋外活動を補完・代替する場として最も重要な場所として位置づけ されていた公園に対する施設側からみた評価と要望についてみてみ ると、日常的に利用寸る公園の数は認可保育所で平均 5.77 箇所、横 浜保育室では平均 3.42 箇所で、施設周辺にある地域資源の中から複 数の公園を日常的に活動する場として担保している様子が示された。 その中で普段最もよく行く公園に対する評価は、「適度な広さがある (83.5\%)」「園外活動に必要なスペースを確保できる $(80.2 \%) 」 「$ 保育所 から近い $(84.5 \%) 」 「$ 季節の変化を感じられる $(74.5 \%) 」$ 等について全 体に「非常に良い」としていた。一方で要望としては、全体に「子ど もが使いや寸いトイレや水飲み場 (47.9\%)」や「幼児用の遊具の充実

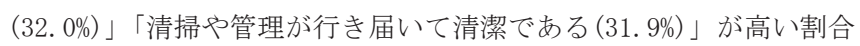
で挙げられていた。

駅前に立地し敷地内に園庭や遊具を保有することが難しい横浜保 育室では、「バギーなどを停めるスペース (公立 $4.2 \%$ ・私立 $7.8 \%$ ・横 浜保育室 53.5\%)」や「安全基準を満たした遊具(公立 $12.5 \%$ ・私立 $13.3 \%$ ・横浜保育室 $41.9 \%$ 」を求める声が多くみられ、認可保育所と は公園に求める要素に差異がみられた(前頁写真 5 参照)。

また、普段よく行く公園に限らず園外活動で利用する場所として選 択する際に重視する公園の特徴として挙げられたのは、全体では「交

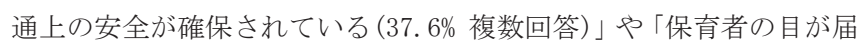
きやすい・死角が少ない $(37.6 \%) 」 「$ 危険な場所が少ない $(36.5 \%) 」 と$ いった安全面が上位に挙げられ、次いで「園外活動に必要なスペース の確保 (33.1\%)」や「清掃や管理が行き届いて清潔である (32.0\%)」な ど公園内部の広さや衛生面に関する項目が多く挙げられた。

その他、前頁図 14 より、横浜保育室では「保育所等から近い

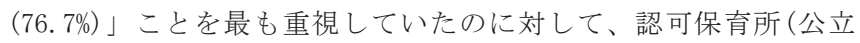
$16.7 \%$ ・私立 $26.7 \%$ ) ではそれほど近さを求める傾向はみられず、不特 定多数の人が行き交う駅前商業地域特有の環境下が起因したとみら れる「近さ」と「安全性」を優先した公園ニーズが抽出された。

\section{6. 結論}

本研究では、保育施設における屋外活動環境の現況と評価及び園外 活動における地域資源の利用実態について考察を行なった。

その結果、得られた知見は以下の通りである。

(1) 保育施設の保有する敷地内屋外環境については施設形態により特 徵がみられ、認可保育所では殆どの施設が園庭を保有し、児童一人当 たりの屋外空地面積は 9.9 m゙でった。これに対して、駅の近くに立 地し、オフィスや商業ビルの一角に併設されるケースが多かった横浜 保育室の園庭保有率は全体の 3 割弱に留まり、児童一人当たりの屋外 空地面積は $2.7 \mathrm{~m}^{2}$ と認可保育所とは開きがみられたことから施設敷 地内に充分な屋外活動スペースの確保が困難な状況にあることが指 摘できる。

(2) 各施設が保有する屋外活動スペースの広さについては、認可保育 所のうち私立の 5 割以上、横浜保育室では 6 割以上が充分ではないと 捉えていた他、遊具・設備や自然環境においても全体に充分ではない と評価している施設の多さが確認されたことから、横浜保育室に限ら ず多くの施設が敷地内だけでは充分な屋外保育活動を行いづらい環 境にあることが浮き彫りとなった。

(3) 本調查を通して園外活動の重要性が改めて示されたが、施設が保 有する屋外活動環境に対する評価が低くなるほど園外活動を行う頻 度が高くなる傾向もみられ、園外に出ることで屋外活動を補填してい る様子が捉えられた。また園庭を保有している場合でも子どもの屋外 活動の意義と重要性を施設側は認識し、多くの保育施設にとって園外 活動は欠かせない保育の一貫として位置づけられていることも示唆 された。

（4）日常の保育活動の場として保育の衫らいに対応させながら施設周 辺にある地域資源を積極的に活用している実態が明らかとなったが、 中でも『公園』と『道』の利用が顕著にみられ、多くの㸚らいを充足 できる重要な活動場所であることが示された。特に『道』については 単なる移動経路としてではなく、子どもたちが多様な体験を積み重ね ていくことができる重要な保育環境であり、公園とともに地域との貴 重な交流空間として利用されていることもわかった。

(5) 多くの施設は、日常的に複数の公園を利用し、保育のねらいや季 節の変化に対応させながら行く場所を選択している様子が窺えたが、 園外活動の場として選択する公園の特徵としては、全体に公園内部の 安全面だけではなくそこに行くまでの経路の安全性が非常に重要視 されていた。歩道橋や駅前、線路沿いなど乗り物がみられる道や自然 と触れ合うことができる道を求める一方で、交通上の安全確保が選択 基準の上位に挙げられていたことから、乳幼児の利用に配慮した周辺 道路や歩道の整備拡充の必要性が指摘できる。

今後は更に限られた環境条件の下、園外活動を行わざるを得ない状 沉にある保育施設が増える傾向にあると思われるが、保育活動の充実 を満たす為には、日常的に利用できる地域資源の存在が久かせない条 件のひとつであり、園外活動の重要性を踏まえた上で施設周辺地域の 整備・拡充を行っていくことが重要といえる。また園外活動の広がり を支える為には地域住民の理解と見守りが不可欠であることから、保 育施設と地域とのつながりを構築させていく為の具体的な取り組み やしくみづくりが課題といえる。

保育施設が活用しや寸い地域資源の充実化を図ることで、敷地内に 
充分な園庭を確保できない施設においては屋外活動を補填・代替でき る可能性が広がり、また園庭を保有する施設にとっても園庭とは別の 㸚らいを充た寸第二の園庭としての役割が期待できることから、今後 は更に公園をはじめ周辺経路や商店街について保育施設が利用しや すい具体的な要件について明らかにし、施設・地域計画の方向性につ いてより考察を深めていきたい。

\section{謝辞}

本研究は (財) 住宅総合研究財団 2007 年度研究助成『保育施設の「屋 外遊戯場」としての公園の代替利用に関寸る研究(代表:三輪律江)』 の一部として実施したものである。また本調查にあたっては子どもの 領域研究所所長 尾木まり氏と埼玉県立大学保健医療学部社会福祉学 科専任講師 高辻千恵氏にご助言を頂くとともに、横浜市こども青少 年局、および横浜国立大学学部生、他関係学生をはじめ各施設関係者 の皆様には多大な御協力をいただきました。末筆ながら記して深く感 謝申し上げます。

\section{注}

注 1) 一般に厚生労働省が定める基淮を満たし都道府県知事(政令指定都市又は 中核市の市長) から保育所設置のための認可を受けている保育所を認可保 育所、受けていない施設は認可外保育所とされ、2008 年の全国の認可保育 所は 2007 年(調查時) より 61 箇所増の 2 万 2,909 箇所で定員は 1 万 5,455 人増加の 212 万 889 人となっている。 2009 年 4 月 1 日現在、全国の待機児 童数は 2 万 5384 人で増加率は過去最高であった。待機児童が最も多いの は東京都の 7939 人で、次いで神奈川の 3245 人 (市区町村別では横浜市が 最も多く 1,290 人)であった。地方では定員に余裕がある一方、都市部(首 都圈: 埼玉 -千葉 - 東京 神奈川、近畿圈: 京都 - 大阪 - 兵庫の 7 都府県と その他) に待機児童全体の 8 割が集中している。また近年の経済環境の悪 化に伴い両親ともに就労しなければならない家庭が増えていることから も今後は更に待機児童は増加傾向にあると思われる。

注 2) 自治体が独自に定めた設置基準を満たし自治体の助成を受けている認可 外の保育施設で、こうした施設は全国的に設置されているという訳ではな く主に待機児童の多い都市部の自治体が殆どである。名称は各自治体によ り様々で、例えば、東京都では「認証保育所」「保育室」、川崎市では「川 崎市認定保育園」等、横浜市は「横浜保育室」で、厚生労働省では『地方 単独保育事業』と呼称している。

注 3）子どもを取り囲む環境は変化し、屋外で全身を使って遊ぶ外遊びの機会 は減少する一方にあり、それに伴い体力の低下や自然体験・実体験の不足、 仲間とのコミュニケーション能力の不足等が社会的な課題として指摘さ れている。また近年、いじめや不登校、自殺といった問題が顕在化してい ることからも、人間形成の基礎となる幼児期において外遊びを通じた体力 の向上と社会性の育成が重要視される傾向にありその必要性は他分野の 研究でも報告されている。(文献 14 参照)

注 4) 2001 年 3 月「待機児童解消に向けた児童福祉施設最低基淮に係る留意事 項等について(厚生労働省雇用均等・児童家庭局福祉課)」より屋外遊戯場 に代わる心゙き場所に求められる条件は「・・1当該公園、広場、神社境内 等については、保育所関係者が所有権、地上権、賃借権等の権限を有する までの必要はなく、所有権を有する者が地方公共団体又は公共的団体の他、 地域の実情に応じて信用力の高い主体等保育所による安定的かつ継続的 な使用が確保されると認められる主体であれば足りる。」と屋外遊戯場の 認定に緩和策がとられるようになり、土地確保が困難で保育所と同一敷地 内に屋外遊戯場を設けることが困難な都市部において特に有効に保育所 増、待機児童の削隇に繋がったとされる。

注 5）本研究では「園外活動」を保育施設内ではできない、または、味わいに くい経験を施設の敷地外の場で行う保育のうち、日常的に行う屋外での活 動を指し、保育施設周辺に出かける日常の散歩も含むと定義し、遠足など のイベントは除外した。

注 6) ここでいう「地域資源」とは地域の中にある物的資源のほか地域住民等
の人的資源も含むこととする。

注 7) 横浜市では低年齢児童 (0.1.2 歳児) を中心に保育所に入所したくても入所 できない待機児童の増加と就労形態の変化に伴い保育ニーズが多様化し ている背景を受けて、1997 年(平成 9 年) 5 月に「緊急保育計画」を策定し た。その中のひとつが「横浜保育室」である。横浜保育室は、認可外保育 施設であるが、横浜市が独自に認定し、保育料・保育環境・保育時間等一 定の基準を設け満たす施設を横浜保育室と認定し、横浜市が助成を行って いる保育施設である。対象は基本 3 歳未満児、定員 20 人以上で、基本保 育時間は午前 7 時 30 分から午後 6 時 30 分でそれ以外の時間外保育も実施 されているほか、夜間保育や休日保育、一時保育も積極的に実施されてい ることも特徴である。保育に従事する職員は $2 / 3$ 以上を有資格者とし、 3 歳未満児は抢拉む称 4 人に保育士を 1 人以上配置することを基準としてい る。更に『乳児室・保育室等の施設設備は児童福祉施設最低基準に準ずる こと。ただし、屋外遊戯場の児童一人当たり面積の設置基準と代替措置の 明記についてはその認定に「屋外遊戯場を有すること」』との条件はある ものの面積基準はなく、「場合によっては付近の公園や屋上利用でも可」 と明記されているのみである。

注 8）今回のアンケートでは児童福祉施設設置最低基準に従い「満 2 歳以上の 幼児」の活動を対象とし、年齢別の設問については年齢による活動の違い や縦割り保育も存在寸ることから 2 歳児または 4 歳児クラス別の緩やかな 設定とした。本稿では 3 歳未満児を対象とする横浜保育室に合わせて、主 に 2 歳児クラスを中心とした報告を行う。本稿での「保育施設」とは調查 の対象となった認可保育所と横浜保育室のこととする。

注 9) ヒアリング対象については、アンケートの回答があった全施設のうちヒア リング調查の許可が得られ、且つ週 1 回以上街区公園の利用がみられる施 設を抽出した。その中からアンケートにおいて園外活動頻度と自由記述の コメント等から園外活動への関心・必要性の高さ、地域交流に対する積極 性が示された施設を保育形態別に偏りがないよう 10 箇所選定した。更に 比較対象として園外活動を行うことが殆どみられない施設 2 箇所を追加し、 全 12 施設をヒアリング対象とした。ヒアリングの内容としては、主に園 外活動の目的と意義・保育計画に対する考えと園外活動との関連づけ・経 路を選択する上で重視する点・地域交流に対する考え等をたずね、園外活 動を行わない施設に対してはその理由と保有する敷地内屋外活動スペー スの使い方・地域交流に対する考え等についてたず叔た。

注 10）保育施設の敷地面積から建物面積を除いた面積（敷地内非建蔽地面積） を敷地内「屋外空地面積」と定義し、「屋外遊戯場となる可能性を持つ空 間」として接地性の高い本来の園庭に近い空間と捉え指標とした。従って 商業ビルなど他の施設と併設されている場合は、敷地は共有部分に值する ので一階部分に保育室を設けている場合を除きすべて $0 \mathrm{~m}^{2}$ とする。またこ の「屋外空地面積」を児童数で割った数值を「児童一人当たりの屋外面積」 とする。駅から施設までの直線距離と面積算出にはゼンリン住宅地図 (文 献 13）を用いた。尚、ゼンリン住宅地図から算出した面積の妥当性につい ては文献 12 により確認されている。

注 11) 屋外活動スペースとは、施設敷地内にある園庭・デッキ・ベンダ(2 階 以上）・屋上等、屋外活動が可能な場所全般のこととする。

注 12）充足度の算出方法については、広さ・設備・自然・安全の 4 項目のうち 「充分である」を 4 点、「まあまあ充分である」を 3 点、「あまり充分では ない」を 2 点、「充分ではない」を 1 点とし各項目を集計、その合計が 14 点以上を『充足度 $A \rrbracket \cdot 11$ 点 13 点を『充足度 $B \rrbracket \cdot 8 \sim 10$ 点を『充足度 $C \rrbracket \cdot$ 7 点以下を『充足度 D』とした。

注 13) 各保育施設では独自の保育方針に従い目標達成を鑑みながら日々保育を 展開している。その為、保育の㸚らいには保育施設のもつ周辺も含めた環 境資源と施設の園外活動に対する考えが特徴として顕れるものといえる。

注 14) 本調查では、屋外での保育の途中で特に子どもたちが楽しみにしている 場所をお楽しみスポットと捉え、具体的な場所について自由記述により回 答を求めた。その結果、認可保育所 107 件、横浜保育室 38 件の回答があ りほぼ全ての保育施設が活動途中での「お楽しみスポット」を保有してい ることが捉えられた。

\section{参考文献}

1）定行まり子、小池孝子：保育施設における外遊びの環境に関する研究一園 庭や公園での遊びを通して見た屋外保育環境一、日本建築学会大会学術講 
演梗概集 E-1 pp. 135-136、2007.

2）小池孝子、定行まり子 : 都市部における保育施設の屋外保育環境について 一東京都区部における複合型保育所の施設環境に関する研究 その 2-、 日本建築学会計画系論文集、第 628 号、pp. 1197-1204、2008.6

3）山田あすか、佐藤栄治、佐藤将之、樋沼綾子：幼保一体型施設における運 営様態, 混合保育, 活動場所の変遷に関寸る研究、日本建築学会計画系論文 集、第 625 号、pp. 543-550、2008. 3

4）山田あすか、上野淳: 保育所における園児の居場所の反復性に関寸る研究、 日本建築学会計画系論文集、第 602 号、pp. 35-42、2006. 4

5）佐藤将之、西出和彦、高橋鷹志:遊び集合の移行からみた園児と環境につい ての考察一園児の社会性獲得と空間との相互関係に関する研究 その 2-、 日本建築学会計画系論文集、第 575 号、pp. 29-35、2004. 1

6）三輪律江、田中稲子、松橋圭子、谷口新、田村明弘：保育施設の「屋外戯 場」としての公園の代替利用に関する研究 - 横浜市における保育施設を対 象としたアンケート調査より-、都市計画論文集、pp. 907-912、No. 43-3、 2008. 10.

7）松橋圭子、三輪律江、谷口新、田中稲子、大原一興、藤岡泰寛：保育施設 における園外活動の実態からみた地域資源の使われ方について一横浜市を 対象としたアンケート調査より一、日本建築学会大会学術講演梗概集、E-1 pp. 195-196、2008.

8）谷口新、三輪律江、松橋圭子、田中稲子 : 保育施設の園庭の有無と園外活 動としての公園利用に関する考察、日本建築学会大会学術講演梗概集、E-1 pp. 197-198、2008.
9）松橋圭子、大原一興、藤岡泰寛、三輪律江、谷口新 : 地域における親子の 居場所からみた子育て支援施設のあり方に関する研究一東京都三鷹市にお ける外出調査より一、日本建築学会計画系論文集、第 600 号、pp. 25-32、 2006. 2

10）谷口新、尾木まり、三輪律江、藤岡泰寬、田中稲子、松橋圭子 : 都市部に おける親子の居場所に関する評価構造について一三鷹市の場合一、日本建築 学会大会学術講演梗概集、E-1 pp. 239-204、2004.

11）谷口新、三輪律江、藤本麻紀子、田村明弘、田中稲子 : 街区公園の利用と 環境条件からみた近隣住民の意識・評価一地域環境計画の視点からみた公園 のユニバーサルデザイン化に関する研究 その 1 一、日本建築学会大会学術 講演梗概集、E-1 pp. 203-204、2005.

12）谷口新、天野克也、仙田満 : 東京都 23 区部および 27 市部における公園整 備特性の類型化と幼児童対象の遊び場の位置づけ、日本建築学会地域施設 計画研究 18、pp. 283-288、2000.

13）(株)エム・アール・シー「ゼンリン住宅地図 (神奈川県横浜市 縮尺 $1: 1500$ )」 (株) ゼンリンプリンデックス

14）日本学術会議 : 対学報告・我が国の子どもを元気にする環境づくりのため の国家的戦略の確立に向けて、2007.07.13

（2009年 9 月 10 日原稿受理，2010年 1 月22日採用決定） 